\title{
Cultural and Political Imaginaries in Putin's Russia
}

\author{
Niklas Bernsand and Barbara Törnquist-Plewa
}

\section{Introduction}

This volume is a part of a series of books published with support of the Centre for European Studies at Lund University dealing with cultural, social and political developments in Eastern and Central Europe in the period after the fall of the communist regimes in 1989-1991. While the preceding books in this series focused on the Balkans (Resic and Törnquist-Plewa 2002), Ukraine and Belarus (Törnquist-Plewa 2006), and Central Europe (Törnquist-Plewa and Stala 2011), this book deals with cultural developments in Russia in the 2000s, a period politically demarcated by the coming to power of Vladimir Putin. The book aims at identifying and analyzing developments in official symbolical, cultural and social policies as well as the contradictory trajectories of important cultural, social and intellectual trends in Russian society after the year 200o. Indeed, several chapters in the book proceed from the perception in Russian society of a fundamental difference between the seemingly less path-dependent first post-Soviet decade of the $1990 \mathrm{~s}$ and the period following the gradual establishment of an authoritarian regime in the subsequent decades. Obviously, a view of the presidential shift from Boris Yeltsin to Vladimir Putin at the start of the new millennium as a symbolic watershed has also served as a recurring rhetorical figure used to prop up the legitimacy of the regime. In this regime-favored view, the 1990s saw the (partial) dismantling of the empire, deadly battles about dividing state property among shady constellations of individuals and corporations, and everyday economic hardships and dysfunctionality, while Putin's Russia of the 20oos offered stability and the strengthening of state institutions, growing prosperity, a successful fight with separatism, the expansion of state borders, and the return of great power status. Such a glaring contrast obviously caricatures actual developments, obscures the personal continuities and policy legacies between the two regimes, and distorts and embellishes policies conducted under Putin. However, this depiction of the 1990 is felt to be real enough by many Russians, and comparisons of the two periods consistently for many come out to the advantage of the latter.

As the title says, this book focuses on the cultural and political imaginaries of Russia since 2000, offering case studies on the vicissitudes of cultural poli-

(C) NIKLAS BERNSAND AND BARBARA TÖRNQUIST-PLEWA, 2019 | DOI:10.1163/9789004366671_002

This is an open access chapter distributed under the terms of the prevailing CC-BY-NC-ND License. 
cies, political ideologies and imperial visions, on memory politics on the grassroot as well as official levels, and on the links between political and national imaginaries and popular culture in fields as diverse as fashion design and pronatalist advertising.

\section{Keeping Them Out, Keeping Them Happy}

In a widespread model of democratisation, the emergence of an economically strong and affluent middle-class will eventually result in demands for political and civic rights. Socio-economic emancipation and the acquirement of cultural and educational capital of this middle segment is thus expected to engender a will for real political influence, respect for property rights, and better quality of government. However, when affluence trickled down fast in Russia during the first part of Putin's rule in the wake of the then high prices on the energy markets, other explanations emerged for why increased (relative) material well-being in a country plagued by corruption and bad governance did not seem to engender a widely supported liberal or reformist opposition. Although coercion and repression in relation to political opposition was and remains part of the regime's toolbox, a common line of reasoning pointed to a social contract (Greene 2017), or a sort of tacit social agreement, being offered by the regime to the younger and more affluent urban layers in Russia. This tacit agreement arguably exchanged political complicity or non-interference of urban professionals in political life and the workings of the government (including them putting a blind eye to how the financial capital of ruling political, bureaucratic and economic elites was and continued to be accumulated) for access to the material and immaterial benefits and possibilities of globalisation. This did not only mean that members of the emerging urban classes to the extent of their financial possibilities could freely travel and have access to the latest technological innovations of global consumerist culture. Their selfrealisation and individual development in terms of education (including foreign) and career opportunities, if not paired with the wrong kind of political ambitions, were also encouraged. This meant that values associated with a global "creative class", such as individualism, creativity and sophistication were embraced and encouraged as long as they remained expressions of individual trajectories (or of use for the state) and did not lead to the emergence of political demands and "class consciousness". In relation to wider segments of the population, it could be argued that the agreement rests on material improvements and on a symbolic rejection of the 1990s, a decade widely perceived as unpredictable, demoralizing, and lawless. 
It would seem a demanding task to uphold such implicit agreements over time and in changing domestic and global political and economic conditions. The financial crisis in 2008, low oil prices as well as the sanctions imposed after Russia's annexation of Crimea in 2014 made it more difficult for the regime to deliver its part of the deal, and in connection with the protests against the flawed elections in 2011 the regime indeed stepped up coercion as a way to deal with political challenges. Kolesnikov (2017) has argued that the patriotic fervor encouraged by state and regime-controlled media in connection with the annexation and the first phases of the war in Ukraine can be seen as a way of offering the citizens a partly remodeled agreement. In this version of the agreement, besides the old promises, Russians would stay out of politics in exchange for enjoying the great power status of their country, which is able to expand and set the agenda in its immediate surroundings and confronts Western ambition in global politics. Some researchers (e.g. Laruelle 2017) argue that the implicit social contract still largely holds, as the distrust of elites remains high, politics is continuously widely considered to be a dirty and unattractive domain, and Putin still enjoys wide support as a symbolic figure beyond politics. Still, analytics like Kolesnikov (2017), points to cracks in the façade as surveys indicate that citizens besides material benefits and great power status now demand better control of tax remedies, which per definition would mean an eventual break with the agreement. The protests in 2017 against the Moscow city government's plans to tear down hundreds of five-storey apartment houses to allow now high-profit high-rise projects, while offering their inhabitants unclear and unsatisfactory compensation, hints to the potential fragility of such social constructs. Networking to organize protests, disaffected members of the younger urban middle class here find allies among teachers, officers and retired people, i.e. from generally loyal sectors of society where few had expected overt discontent (Baunov 2017). Interestingly, some protesters felt as if the 1990s had returned (ibid), which could be seen as perception of a break with the tacit social agreement from the government's side.

\section{Activating Them And Curbing Their Enthusiasm}

However, as Laruelle argues, the regime cannot work only with strategies of demobilization, e.g. through tacit social agreements - it could also benefit from actively mobilising support, for which ideological content would be necessary. The nature of such a content is the object of competing analyses and constructs. In earlier phases of the Putin regime observers (e.g. Aslund 2012) have tried to discern the shifting battles for influences between more liberal 
and more authoritarian camps associated with the Kremlin. As expansionist politics leading to the annexation of Crimea were accompanied with great power rhetorics and situational alliances with various nationalist groups, and Russian support for European populist right-wing parties increasingly caught attention, voices in Western media sometimes began to perceive the Putin regime in itself as radically right-wing (e.g. Inozemtsev 2017), designations which would need strong qualifications. For others, like the Russian-British journalist Peter Pomerantsev, the regime is rather a "postmodern dictatorship", a skillful situational adapter and compilator of contradictory social and cultural and political trends and currents, the manipulation of which can make it "feel like an oligarchy in the morning and a democracy in the afternoon, a monarchy for dinner and a totalitarian state by bedtime" (Pomerantsev 2014, 67). The key assumption here emphasises the regime's willingness to appropriate, imitate and distort the content of almost anything that might come to resemble real politics (with distinctive and uncontrolled actors having a real social base), and thus defuse the disruptive capacity of potentially threatening social movements or platforms. This understanding works well with Andrew Wilson's (2005) earlier term virtual politics for the way the political scene in itself has been manipulated and set up in some Post-Soviet societies.

In Laruelle's (2017) analysis, the regime presently rather maintains an "explicit but blurry conservatism", a flexible and adaptable doctrine built around a few common basic ideological tenets such as anti-Westernism, antiliberalism, and "traditional values". This ideological umbrella unfolds a large implicit ideological diversity that allows Russians to be inspired from contradictory and potentially conflicting "red" and "white" ideological packages, e.g. Soviet and Tsarist, Russian ethno-centrist and a multiculturalist celebration of cultural diversity within the empire. However, various instantiations of rebranded Soviet nostalgia is the single most important strand. Blurry conservatism has been selected for the present situation since it meets the least active opposition, mainly from a limited number of urban liberals (and can from time to time absorb "liberal" technocrats into the regime). In comparison, an outright and consistent, long-term embrace of a Russian ethno-centric nationalist outlook would risk being much more divisive.

Against the backdrop of such a gambit of "blurry conservatism" the regime has in the last few years increasingly sought cooperation with conservative forces and social movements in certain fields, such as the cultural sector, and in policies encouraging child birth (see Jonson's and Rakhimova-Sommers' respective chapters), and also with commercial actors such as in the fashion industry (see Kalinina's chapter). The visibility of the Orthodox Church in political and symbolic state-level contexts has also been more clearly empha- 
sized. Whether this makes the regime politically and ideologically conservative in a meaningful sense is up for debate. As was outlined in connection with the tacit social agreement with the young creative urban class, advanced technology and, at least superficially, the connected packages of representations and associations are accepted, while there is little interest in political reforms, more effective institutions and power sharing. The term conservative modernization (see e.g. Trenin 2010) that at earlier stages has been used for the regime's policies and is historically identified with attempts in the late Tsarist period at reforms in order to preserve the existing political order, seems less relevant at this moment, as the meaning of both those elements for present Russian policies is unclear. The key goal for which tacit social agreements are calibrated and selective mobilization can be instrumentalised, is arguably the preservation of the regime itself. At most one might perhaps distinguish a few almost pre-political convictions or reflexes in the Russian leadership - firm central control internally, the vision of Russia as a great power dominating the area of the former Soviet Union, multipolarity at the global stage etc.

How, then, does this relate to ideological developments at the grassroot level? Some of the chapters in this book (Jonson on cultural politics, Morenkova on the memory of Stalinism, Kalinina on fashion design), give a clear indication that grassroot activism and ideological developments in various professional fields in contemporary Russia is an ideologically complex phenomenon (see also Chebankova 2015). The grassroots level is not necessarily a site of resistance generating liberals and human rights activists but can be activated in favor of the regime, as well as opposing the regime from even more illiberal standpoints.

\section{Outline of the Volume}

The chapters are organized according to the three different cultural-social spaces investigated: cultural policies and ideological movements behind them, mnemonic politics and culture, and last but not least popular culture and its embeddedness in politics.

The first part of the book looks at cultural policy in Putin's Russia and points to its connection to changing concepts of Russian national identity, geopolitical imaginary and nationalist ideologies of different leanings. Thus, it starts with the chapter by Lena Jonson that analyses the change of cultural and political values in Russia as reflected in dramatic turn in Russian state's policy towards the cultural sector since 2012. Jonson discusses how this turn came about by focusing on small intellectual communities that were crucial for 
formulating ideas and concepts for cultural, social and political change. These groups, which Jonson calls "critical communities" included both liberals and conservatives. Both created during the 2000 s small embryos of social movements that confronted the Russian system. After the protest movement 20122013 the liberals were significantly weakened while the conservatives got the upper hand since their ideas were adopted by the Putin regime. This had a profound impact on the cultural sector.

Jonson's account is followed by the chapter written by Igor Torbakov. He nuances further the picture of Russian liberalism and conservatism by demonstrating how the legacy of the ideological and intellectual construct called Eurasianism is used both by conservative and liberal nationalists in contemporary Russia. While the Kremlin with the help of some conservatives exploits Eurasianism to legitimise the concept of "Russian World" with a clear neo-imperial strand, there are both conservatives and liberals that deplete it to argue for abandoning the imperial ambitions and create a smaller, but stronger Russian nation. Thus the struggle over what should constitute the main pillars in the construction of Russian identity continues.

One of the extreme political groups involved in this struggle is Eduard Limonov's National Bolshevik Party (currently part of the Other Russia party coalition). Andrei Rogatschevski looks closely at this phenomenon in the third chapter of the book. He scrutinizes the NBP's s ideology (especially ethnic policy), its symbols and practices and asks how close the party is to a Neo-Nazi movement. Rogatschevski's conclusion is that the party has Nazi roots and displays features typical for Fascists. For a long time since its creation the party was rather marginalised and at the beginning of 2000 s was even in conflict with the Kremlin due to its militancy. However, in face of the war in Ukraine in 2014-2015 they sided with each other and The Other Russia is a strong supporter of separatists in Eastern Ukraine.

The second part of the volume is concerned with politics of memory. Collective memory understood as representations of the past shared within the group and used to support the group's identity and cohesion is a tool that any political power tries to exploit (as widely argued for example by Connerton (1998), Olick (2007), Bernhard and Kubik (2014). Russian political rulers are no exception in this regard. At the same time, they face a society which is painfully torn in its relation to the Soviet past trying to reconcile the memories of "the glorious past" of the Soviet empire, a victor in the Second World War, with the tragic memories of Stalin's mass killings and Communist repressions. Three chapters of the volume deal with this complex subject. The first one is written by Olga Malinova and gives an overview of the evolution of the memory policy of Russian Federation over the last twenty five years. She shows how 
the construction of the official narrative of the past takes place in official speeches, the so called Memory Laws (i.e. legislation that restricts particular ways of public representation of some historical events or processes) state symbols, national holidays, official and unofficial rituals, etc. She argues that in the 1990s the official narrative had integrated a discourse about "trauma and crime" as a part of legitimization of the post-Soviet transformation, but in the 2000 s the choice was gradually made for an apologetic principle that marginalizes this topic. In the 2010s, however, one can notice attempts to create an eclectic official narrative which brings, in her view, ambivalent results. On the one hand the apologetic conception of the national past is very strong and even securitized as a "weapon" against the alleged foreign and domestic enemies. On the one hand, there are some opportunities opened for actors struggling for "coping with the difficult past".

A good illustration how it is done can be found in the next chapter, written by Tomas Sniegon who analyses how Gulag memory is framed in some crucial sites of memory of political repressions in Russia: the former execution site in Butovo, one of Moscow's suburbs; the State Museum of Gulag History in Moscow, and the museum and former labor camp Perm-36 in the Ural region. Sniegon argues that in recent years a new common "patriotic" narrative of the Gulag is developing under the control of the state. The Gulag is not necessarily denied, but the memory of communist terror and crimes is not framed within liberal discourse. Instead the public at the sites in question is presented with narratives in which the new nationalist perception of the Gulag memory converges with the religious, Orthodox and Soviet-nostalgic views of the past.

Sniegon's contribution is followed by another, case-based study which deals with memories on the role of Stalin in Second World War in Post-Soviet Russia. The study conducted by Elena Morenkova Perrier complements the previous chapters by focusing not so much on public memory and its representation but more on the reception of it. Morenkova Perrier focuses on grass roots' reactions to critical memory of Stalin, the so called trauma and crime discourse described by Malinova in the chapter 4. By exploring the new memory-related practices and activism within Russian social media, Morenkova shows the socially divisive effects of this discourse, as it both engenders support and triggers resistance. She examines debates and mobilisations, both online and offline, generated by two controversial memory initiatives in 2010 and 2011 at the local and federal level concerning the re-evaluation of Stalin's role in the Great Patriotic War. Focusing on the tension between two intertwined symbols - the controversial figure of Stalin and the sacred symbol of the Victory she brings to light the complex attitude towards historical Stalinism within contemporary Russian society. 
The third and last part of the volume pays attention to popular culture and provides examples of how its different expressions and media are used as a propaganda tool in the service of the state politics and ideology. It also brings to the fore the workings of what Michael Billig (1995) called banal nationalism - the seemingly non-ideological, everyday representations of the nation. This part begins with a study by Elena Rakhimova-Sommers who analyses Russian pronatalist ideology as expressed in a state-sponsored "boost the birth rate" campaign, which was a response to a sharp demographic decline during the severe economic crisis of the post-Soviet era. Rakhimova-Sommers' study offers "a window into the workings of a new pronatalist ideology that focuses on creating associations between fertility and ethnic and national homogeneity" (p. 177 in this volume). The study demonstrates that in the 2000s, the Russian state adopted a more active role in the sphere of bio-politics, as motherhood had become increasingly defined in terms of social success and patriotic duty. Rakhimova-Sommers discusses the state's interpretation of the "women's question," the changing dynamics of the state-mother-child relationship, and the notion of the "absent father" in this gendered post-Soviet space. As Rakhimova-Sommers examines a series of emblematic billboards and commercials, she takes the reader inside the mechanics of the advertising industry's methods, which aim to capitalize on the anxieties of young women.

The following chapter, written by Ekaterina Kalinina, further develops and deepens the discussion on how the Russian state uses the visual means of popular culture to extend its power over both the physical and political bodies of a population. Kalinina shows how fashion is employed to ideologically indoctrinate masses. Targeting predominantly young people, the Kremlin designers strive to intensify myths about World War II, celebrate the current rulers and facilitate the mobilisation of the state ideology, in which the authority of the present dictates a certain presentation of the past. The author discloses that these propagandistic manipulations take place under cover of ironic, humorous, "postmodern" designs, which increases their effect by disarming and confusing the public.

This important idea about the ambiguous functions of irony and humor, not least as instruments of political power is a point of departure of the next chapter, which is a result of collaborative work by three researchers: Alena Minchenia, Barbara Törnquist-Plewa and Yuliya Yurchuk. The authors examine the content of a selected number of Russian political jokes and humorous cartoons, presented in popular Russian TV-programs and dealing with Belarusian and Ukrainian leaders. The scholars investigate how Russian-Belarusian and Russian-Ukrainian relationships and Russia's self-perception feature in these representations. Their analysis shows that the comical representations serve to 
conserve the existing ethnic stereotypes of Belarusians and Ukrainians and to maintain the Russian feeling of superiority over its neighbours. This kind of humour bolsters Russian nationalism and at the same time tries to conceal Russia's imperialist stance by presenting the Russian state as a benevolent power that is ready to support and help its neighbours. The authors argue that Russian humour in this context can be seen as tool of hegemony and expression of the colonial legacy.

The last chapter of the volume, written by Natalia Majsova, delivers yet another example of how political messages can be smuggled in cultural expressions that on the surface have nothing to do with political power. Majsova studies the Russian phenomenon of "noocosmology" - a project (or a set of ideas), propagated via internet that mimics scientific discourse in form and at the same time broadcasts a secular but quasi-religious worldview. Noocosomology uses Soviet nostalgia, more precisely some parts of the tradition of so the called cosmists (the founding fathers of the successful Soviet space program) to preach a new, seemingly science-based metaphysics, It has some similarity with scientology in the West, but also displays some common features with post-gravity art and astrosociology. Remarkably, noocosmology appoints the Russian security services to play the role of a kind of priesthood in this non-proclaimed religion. They are endowed with a special, educational if not messianic mission not only in Russia but in the global community as well - assigned to be the mediators between the higher spirts of the universum and human beings. Considering that the activities of the Western churches and scientology are prohibited by law in Russia, noocosmology can be seen as one of a number of Russian equivalents of the Western spiritual movements, including new age phenomena. However, its celebration of Russian security forces implies that the project also has a political agenda. It can be seen in light of its usefulness for the current Russian rulers that can exploit peoples' metaphysical longings to uphold their power.

The editors and the authors of this volume would like to gratefully acknowledge the support of Centre for European Studies at Lund University that made the publishing of this book possible. Our thanks also go to Mr. Justin Sammon, student at Master of Arts Programme in European Studies in Lund, who helped with the technical editing of the volume during his internship at the Centre. 


\section{References}

Aslund, Anders. 2012. "Russia's surprisingly liberal new cabinet”. Foreign Policy, May 22, 2012. Accessed February 1, 2017. <http://foreignpolicy.com/2012/05/21/russias-sur prisingly-liberal-new-cabinet/>.

Baunov, Aleksandr. 2017. "Neblagodarnye piatietazhki. Pochemu vlast' stolknulas's protestom tam, gde ne zhdala”. Moskovskii Tsentr Karnegi Accessed February 1, 2017. $<$ http://carnegie.ru/commentary/69965>.

Bernhard, Michael and Kubik. Jan. 2014. Twenty Years After Communism, The Politics of Memory and Commemoratioan, Oxford: Oxford University Press.

Billig, Michael. 1995. Banal Nationalism, London: Sage Publications.

Chebankova, Elena. 2015. "Competing Ideologies of Russia's Civil Society”. Europe-Asia Studies 67, no. 2 (March).

Connerton, Paul. 1989. How Societies Remember, Cambridge: Cambridge University Press.

Greene, Samuel E. 2017. "From Boom to Bust: Hardship, Mobilization \& Russia's Social Contract”. Daedalus 146, Issue 2 (Spring).

Inozemtsev, Vladislav. 2017. "Putin's Russia: A Moderate Fascist State". The American Interest 12, no. 4. Accessed February 1, 2017. <https://www.the-american-interest. com/2017/01/23/putins-russia-a-moderate-fascist-state/>.

Kolesnikov, Andrei. 2017. "Obshchestvennyj dogovor 3.o". Moskovskii Tsentr Karnegi. Accessed February 1, 2017. <http://carnegie.ru/2017/05/o1/ru-pub-69834>.

Laruelle, Marléne. 2017. "Putin's Regime and the Ideological Market. A Difficult Balancing Game”. Accessed February 1, 2017. <http://carnegieendowment.org/2017/03/ 16/putin-s-regime-and-ideological-market-difficult-balancing-game-pub-68250>.

Olick, Jeffrey K. 2007. The Politics of Regret: On Collective Memory and Historical Responsibility. New York: Routledge.

Pomerantsev, Peter. 2014. Nothing is True and Everything is Possible. The Surreal Heart of the New Russia. New York, Public Affairs.

Resic, Sanimir \& Törnquist-Plewa, Barbara (eds.). 2002. The Balkans in Focus. Cultural Boundaries in Europe. Lund: Nordic University Press.

Trenin, Dmitri. 2010. "Russia's Conservative Modernization. A Mission Impossible?" SAIS Review of International Affairs 30, no. 1 (Winter-Spring).

Törnquist-Plewa, Barbara (ed.) 2006. History, Language and Society in the Borderlands of Europe. Ukraine and Belarus in Focus. Malmö: Sekel.

Törnquist-Plewa, Barbara \& Stala, Krzysztof (eds). 2011. Cultural Transformations after Communism: Central and Eastern Europe in Focus. Lund: Nordic Academic Press.

Wilson, Andrew. 2005. Virtual Politics: Faking Democracy in the Post-Soviet World. New Haven and London: Yale University Press. 
PART 1

Cultural Policy and Ideological Movements 